\title{
PNNL Information Technology Benchmarking
}

D. D. Hostetler"

J. E. Goolsbey

D. A. Niesen

A. C. Phillips

August 1999

*e-mail: david.hostetler@pnl.gov

phone: (509) 375-2293

fax: (509) 375-3641

mailing address: Information Sciences \& Engineering

Pacific Northwest National Laboratory

P.O. Box $999, \mathrm{~K} 7-22$

Richland, WA 99352

This paper was developed by the Information Sciences and Engineering group at the Pacific Northwest National Laboratory, which is operated by Battelle Memorial Institute under Contract DE-AC06-76RLO 1830 for the U.S. Department of Energy. 


\section{DISCLAIMER}

This report was prepared as an account of work sponsored by an agency of the United States Government. Neither the United States Government nor any agency thereof, nor any of their employees, make any warranty, express or implied, or assumes any legal liability or responsibility for the accuracy, completeness, or usefulness of any information, apparatus, product, or process disclosed, or represents that its use would not infringe privately owned rights. Reference herein to any specific commercial product, process, or service by trade name, trademark, manufacturer, or otherwise does not necessarily constitute or imply its endorsement, recommendation, or favoring by the United States Government or any agency thereof. The views and opinions of authors expressed herein do not necessarily state or reflect those of the United States Government or any agency thereof. 


\section{DISCLAIMER}

Portions of this document may be illegible in electronic image products. Images are produced from the best available original document. 


\section{Table of Contents}

PURPOSE
BACKGROUND
PERFORMANCE MEASURES IN THE CONTEXT OF ENTERPRISE MEASUREMENT MODEL
EXPECTED RESULTS KEY PERFORMANCE MEASURES
Benchmark Data
Benchmark AnalySiS
REFERE WORK 


\section{PNNL Information Technology Benchmarking}

\section{Purpose}

This document describes the Pacific Northwest National Laboratory's (PNNL's) approach to information technology (IT) benchmarking. The purpose is to engage other organizations in the collaborative process of benchmarking in order to improve the value of IT services provided to customers. This document's intended audience consists of other U. S. Department of Energy (DOE) national laboratories and their IT staff. Although the individual participants must define the scope of collaborative benchmarking, an outline of IT service areas for possible benchmarking is described.

\section{Background}

Benchmarking is a methodology for searching out industry best practices that lead to superior performance. It is exchanging information, not just with any organization, but with organizations known to be the best within PNNL, in industry, or in dissimilar industries with equivalent functions. It is used as a continuous improvement tool for business and technical processes, products, and services. Information technology - comprising all computer and electronic communication products and services - underpins the development and/or delivery of many PNNL products and services. We have the continuing goal to improve the value of IT through better quality and cost-effectiveness of IT infrastructure services, products, and support to match the Laboratory's strategic, operational, and investment requirements. This goal is accomplished by actively managing the IT core investment portfolio (core refers to overhead-funded basic services offered to all staff with no direct fee for use or charge-back). As illustrated in Figure 1 , PNNL is implementing a more systematic approach for investment planning by adding two key tools: formal service-level agreements with internal customers and external benchmarks against peer groups. Although both are tools for measuring and communicating the relative value of IT investments to the overall business, this document focuses on benchmarking and benchmarks, not service-level agreements.

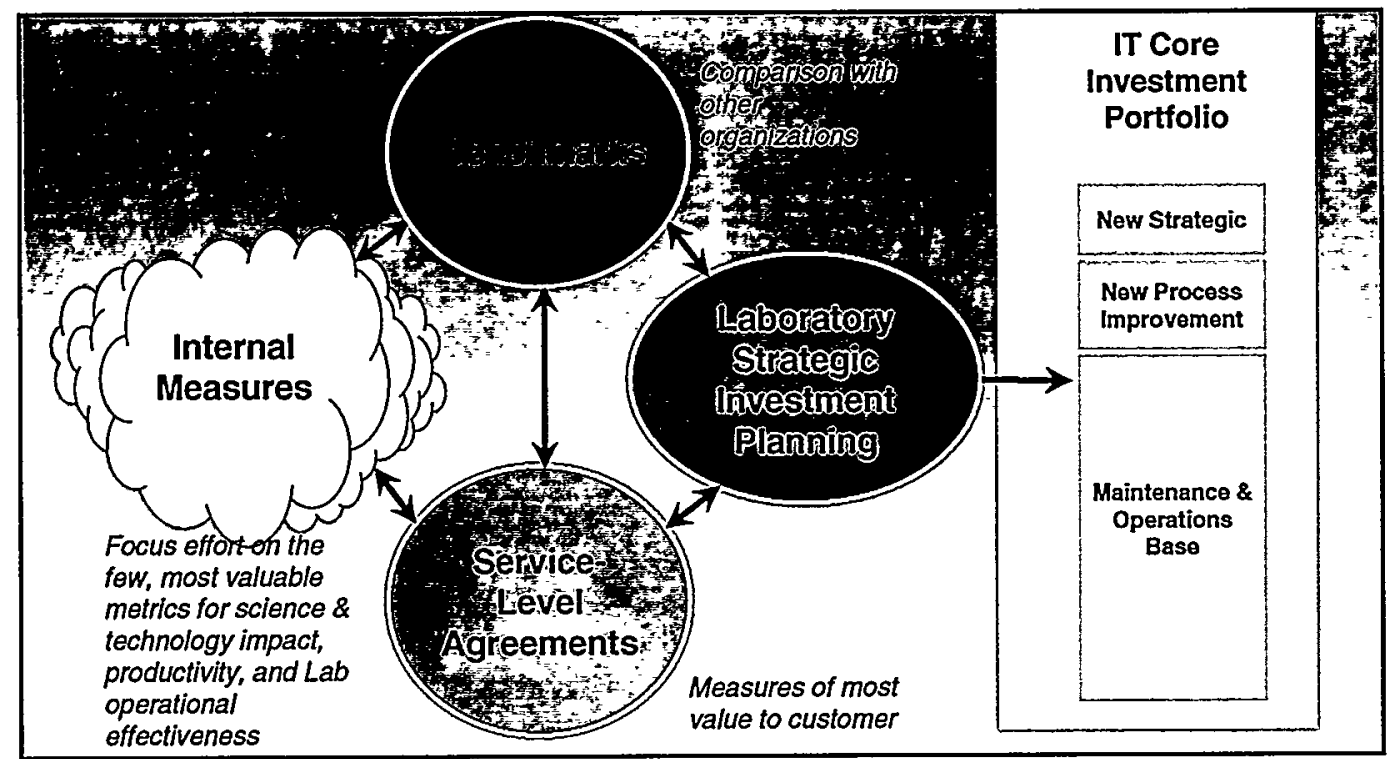

Figure 1. IT Business Planning Process Showing Benchmarking and Service-Level Agreements

Benchmarking is not the same as benchmarks. Benchmarks are performance measures: How many? How high? How low? How quickly? Benchmarking is action - discovering the specific practices responsible for high performance, understanding how these practices work, and adapting and applying them to our organization [1]. As an overall goal, the IT benchmarking process will formalize current "ad hoc" benchmarking, establish better consistency in performance measures, and extend comparisons to a larger number of external organizations in both the public and private sectors. 


\section{Performance Measures in the Context of Enterprise Measurement Model}

Performance measures are an important tool for many complex operations, including adapting businesses to changing market conditions. Performance measures exist at many levels in an organization from strategic to operational. Figure 2 illustrates an Enterprise Measurement Model for PNNL, which has been adapted from the GartnerMeasurement Model [2]. In the past, organizations have emphasized cost and process efficiency (doing things right). Today, organizations are emphasizing overall business effectiveness (doing the right things) in order to achieve a better balance between efficiency and effectiveness. While monitoring operational performance is important, linking and aligning with strategic enterprise business objectives is paramount. The Enterprise Measurement Model provides a framework for this linkage, which is described in more detail later in this document (see Figure 3).

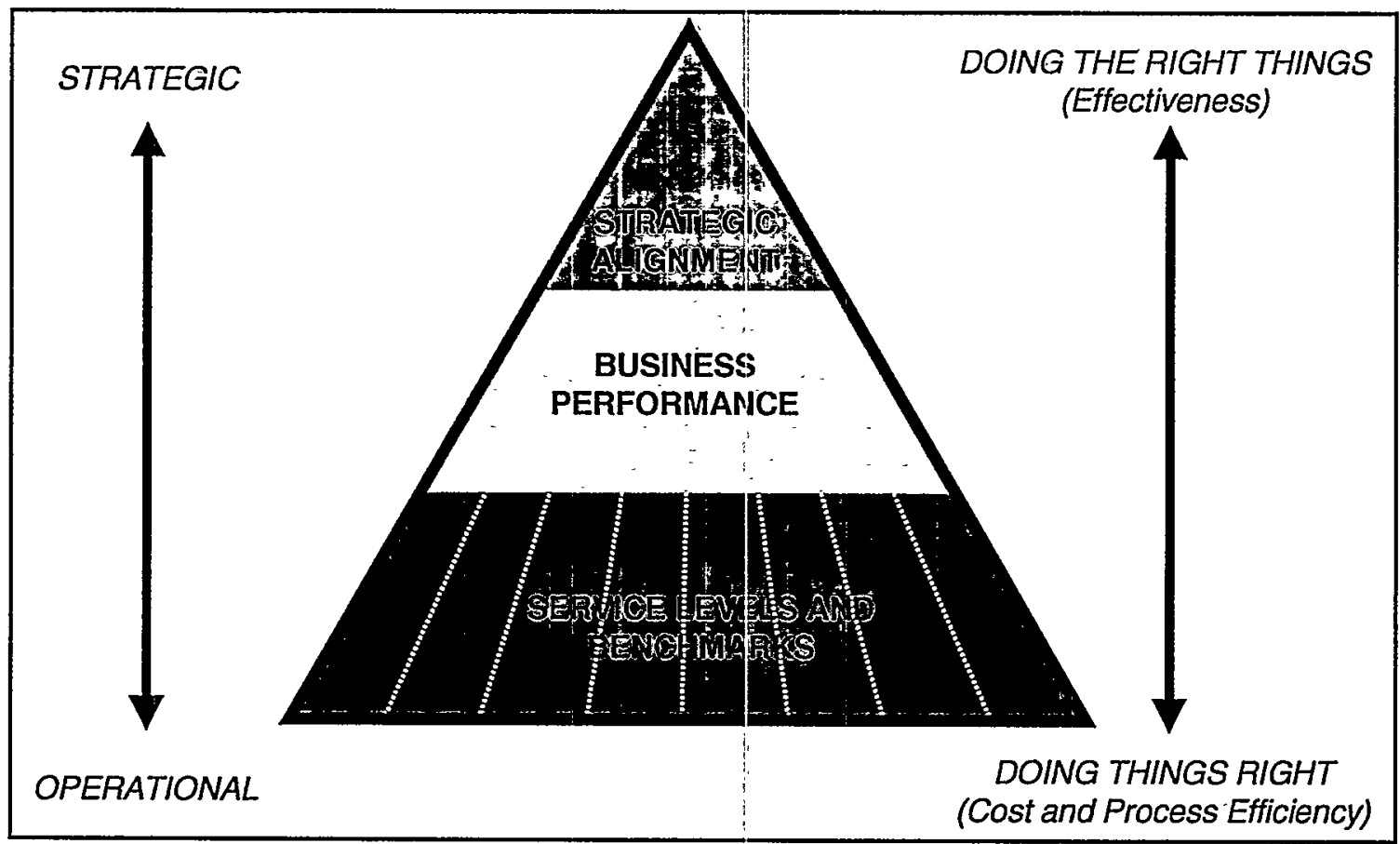

Figure 2. PNNL Enterprise Measurement Model (Based on GartnerMeasurement Model)

Business change is accelerating, driven by the competitive global marketplace and new technologies. Managing business change is essential to success. Measurement is an important tool in monitoring and communicating business goals and performance throughout the organization, top to bottom.

Performance measures are an important part of benchmarking. They are indicators of value provided to customers and can serve as a basis of comparison (e.g., to historical trends, to other organizations). Performance measures can be broadly based on cost or quality. Quality-based measures include all non-cost measures such as capacity, quantity, speed, and response. Taken together, cost and quality measures should indicate the value of a selected product or service.

\section{Methodology and Key Performance Measures}

Consistent with PNNL's methodology, the benchmarking process can be broken into four iterative phases:

- plan

- collect

- analyze and compare

- adapt and implement improvements. 
This iterative process is intended to be continuous over multiple years, and an integral part of IT business planning. Identifying key performance measures of most value to internal customers and implementing the benchmarking process itself can be difficult tasks. To establish meaningful and comparable benchmarks, PNNL must select peers in the private and public sector that have similar business objectives and IT infrastructures. It is fundamental that PNNL understand its internal structure and business needs with respect to IT services in order to determine the essential items to compare externally.

Table 1 describes typical characteristics of cost- and quality-based performance measures. The unit of time for a performance measure will vary (i.e., weekly, monthly, and yearly) ${ }^{*}$.

Table 1. Typical Characteristics of Performance Measures

\begin{tabular}{|l|l|}
\hline Cost-Based Measures & Quality-Based Measures \\
\hline$\$ /$ staff/month & Outage impact (staff hours/month) \\
\hline$\$ /$ unit of service/month & Service delivery timeliness \\
\hline \$/user/month & $\begin{array}{l}\text { \# of products delivered (avg. \# of messages } \\
\text { per staff / month) }\end{array}$ \\
\hline$\$ /$ full-time employee (FTE)/month & $\%$ of capacity used \\
\hline
\end{tabular}

Benchmarking can be conducted at multiple levels within an organization. At least three separate levels can be identified:

- Highest Level - Overall business profile that includes some summary IT information in the context of the organization (see Table 2). The business profile attempts to estimate relative investment in and distribution of IT resources throughout the organization (i.e., resources controlled by a central IT department vs. resources controlled by.business units).

- Intermediate Level - Specific IT service areas that measure value of IT to customers (see Table 3 for ITspecific service areas supported by PNNL). The most important performance measures are those found in service-level agreements with customers (i.e., what customers value and consider measurable).

- Detailed Level - Drill down to operational details within specific service areas - for example, the cost of long distance services alone within the overall telephone services area. Detailed benchmark assessments will be selective, based on perceived opportunities and access to comparable data.

Table 2. Example Performance Measures for a High-Level Business Profile

\begin{tabular}{|l|l|l|}
\hline Business Profile & Cost-Based Measures (/yr) & Quality-Based Measures (/yr) \\
\hline Organization profile & $\begin{array}{l}\text { Total business revenue (\$); Revenue } \\
\text { per staff; Revenue per FTE; Revenue } \\
\text { per worker (staff+contractors) }\end{array}$ & $\begin{array}{l}\text { Total staff; total FTE; total contrac- } \\
\text { tors; total contractor FTE; Direct to } \\
\text { indirect labor ratio }\end{array}$ \\
\hline $\begin{array}{l}\text { Organization-wide IT profile } \\
\text { (all computing \& communica- } \\
\text { tions, includes business units) }\end{array}$ & $\begin{array}{l}\text { Total IT budget (\$); IT Budget per } \\
\text { staff }\end{array}$ & $\begin{array}{l}\text { Total IT staff; total IT FTE; total IT } \\
\text { contractors; total IT contractor FTE }\end{array}$ \\
\hline $\begin{array}{l}\text { Central IT Department profile } \\
\text { (central information system } \\
\text { department) profile }\end{array}$ & $\begin{array}{l}\text { Total department budget (\$); IT } \\
\text { Budget per staff }\end{array}$ & $\begin{array}{l}\text { Total department staff; total depart- } \\
\text { ment FTE; total department contrac- } \\
\text { tors; total department contractor FTE }\end{array}$ \\
\hline
\end{tabular}

\footnotetext{
- There are distinctions in people resource units: staff = entire organization headcount; FTE = entire organization headcount adjusted for full time; user $=$ actual user count where available and appropriate.
} 


\section{PNNL IT Benchmarking}

Table 3. Example Performance Measures for IT Service Areas

\begin{tabular}{|l|l|l|}
\hline IT Service Area & Cost-Based Measures (/month) & Quality-Based Measures (/month) \\
\hline Telephones & \$/staff; \$/minute; \$/line & $\begin{array}{l}\text { \# of telephone lines; \# of service requests; \% } \\
\text { problems solved in guaranteed response time }\end{array}$ \\
\hline $\begin{array}{l}\text { Productivity } \\
\text { (Desktop Tools) }\end{array}$ & \$/staff; \$/user; \$/FTE & $\begin{array}{l}\text { Avg. e-mail delivery time; e-mail volume - \% of } \\
\text { capacity }\end{array}$ \\
\hline $\begin{array}{l}\text { Customer Support } \\
\text { (Help Desk) }\end{array}$ & \$/staff; \$/call & $\begin{array}{l}\text { \# of service requests; \% problems solved in } \\
\text { guaranteed response time; avg. time in call queue }\end{array}$ \\
\hline $\begin{array}{l}\text { Unclassified } \\
\text { Computer Security }\end{array}$ & \$/staff & $\begin{array}{l}\text { \% of staff yet to complete security training; \# of } \\
\text { incidents }\end{array}$ \\
\hline Network Services & $\begin{array}{l}\text { \$/staff; \$/bandwidth (LAN); } \\
\text { \$/device (WAN); \$/GB (servers); } \\
\text { \$/bandwidth (WAN portal); } \\
\text { \$/e-mail message }\end{array}$ & $\begin{array}{l}\text { File server outages impact (staff hr / month); \% of } \\
\text { capacity for each - desktop bandwidth, backbone } \\
\text { bandwidth, Internet-access bandwidth }\end{array}$ \\
\hline Business Computing & \$/GB; \$/staff; \$/user & $\begin{array}{l}\text { Business computing outages impact (staff hr / } \\
\text { month) }\end{array}$ \\
\hline $\begin{array}{l}\text { Strategy \& Business } \\
\text { Planning }\end{array}$ & \$/staff; \$/FTE & Strategic alignment attributes \\
\hline
\end{tabular}

\section{Expected Results}

Benchmarking is a continuous and iterative component of the strategic, investment planning process. Results are expected in two forms: benchmark data and benchmark analysis. Expected results should then improve management of the IT Core Investment Portfolio (see Figure 1, right-hand side) in order to provide "optimal" business value of IT.

\section{Benchmark Data}

Benchmark data will be developed incrementally for specific, targeted comparisons. Figure 3 illustrates the range of performance measurement and communication tools available within the context of an Enterprise Measurement Model. The purpose of these tools is to provide better linkage, as appropriate, between critical outcomes at the highest level of the organization and lower-level operational performance measures for individual service areas like telephones and networks. The mid-level measurements that assess business performance are key. These measures are selected as the strongest indicators of business impact from an internal customer's viewpoint. For example, PNNL's Energy Division uses a "balanced scorecard" to monitor Division performance contributing to the Lab's critical outcomes [4]. Within the Energy Division, the IT Department contributes some performance measures for the scorecard and will enhance communication with the addition of an I'T dashboard (dashboards simply display key performance measures in a way people are accustomed to, like dials on motor vehicle dashboards). IT customer satisfaction and overviews are performance assessment tools that contain added detail about service areas. Benchmarking can occur at any level within the organization and across functional organizations, but most IT benchmark data will be based on IT services shown in the bottom third of the model pyramid. These benchmark data provide a basis for "composite" measures for assessing business performance and the value of IT to customers. Benchmark data must be normalized for an "apples-to-apples" comparison, which is often difficult. Typically, comparisons are assigned a level of confidence (high, medium, and low) that data are indeed accurate and comparable. 


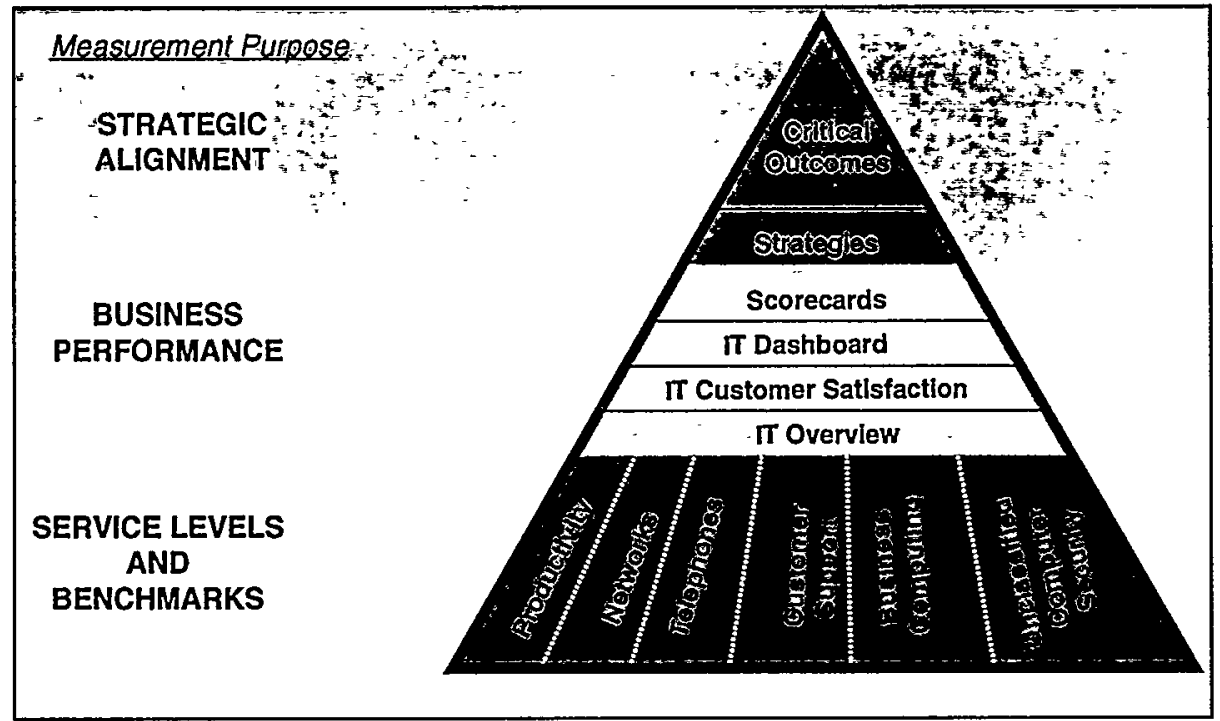

Figure 3. PNNL Enterprise Measurement Model and Monitoring/Communication Tools

\section{Benchmark Analysis}

Benchmark analysis uses comparable data to identify process improvement opportunities and recommendations. Process improvements can involve any combination of operations staff, technologies used, or appropriate outside resources. For "apples-to-apples" comparison, performance must be normalized for service level and IT environment complexity (e.g., number of service levels, number of desktop operating systems, average number of devices per staff, customer support response times); as Heine notes, "Increased complexity in the distributed computing environment leads to substantial increases across all cost areas."[3] Service areas that do not meet business needs and expectations relative to best practices are targeted for process improvement and appropriate investment. Figure 4 illustrates for a specific example of how price is compared to performance during analysis. The example shows the cost to provide network connectivity of specific bandwidth to a typical desktop workstation.

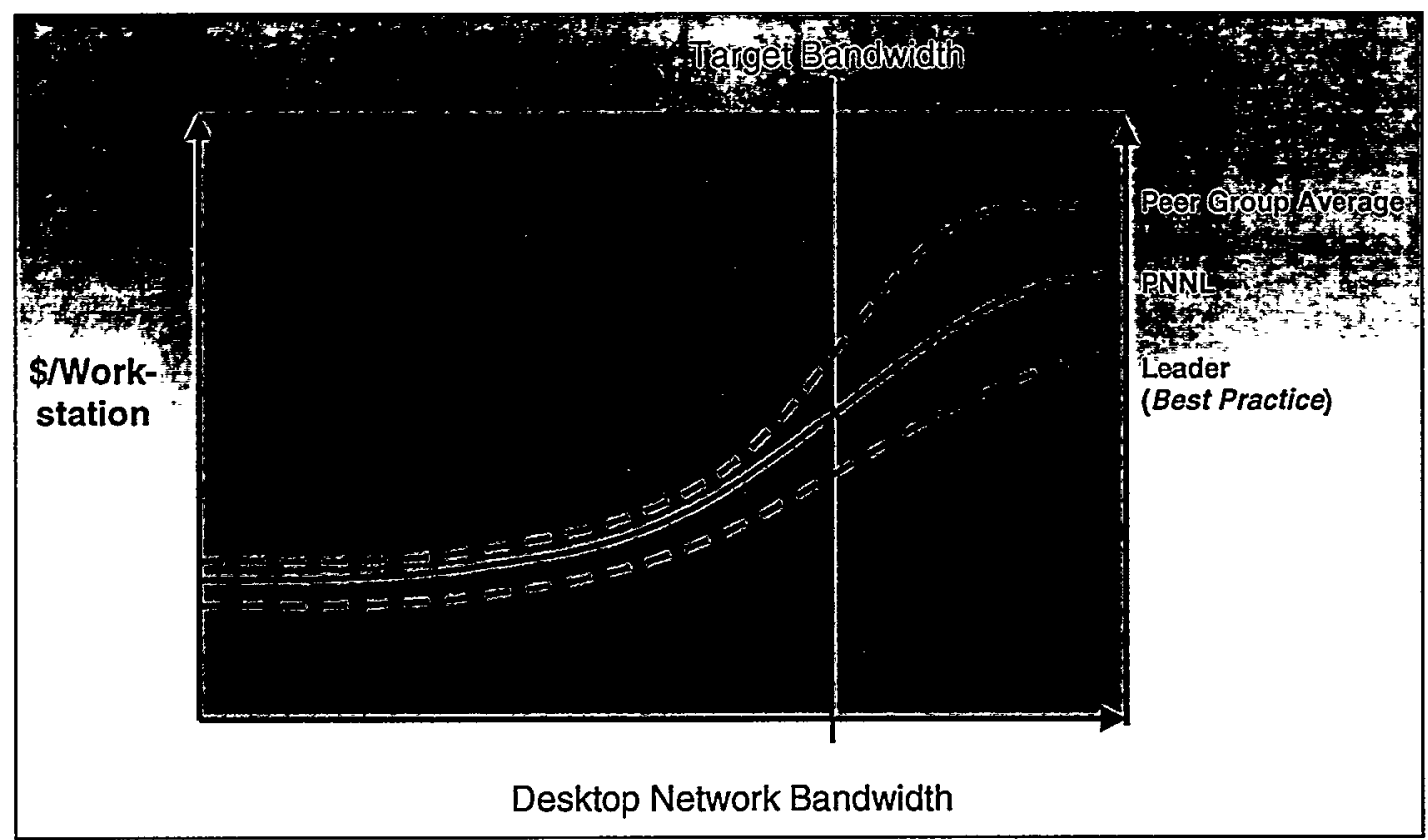

Figure 4. Benchmarking Price vs. Performance for Desktop Network Bandwidth 


\section{Future Work}

Expected results will be developed over time in three phases: 1) internal assessments, 2) comparisons with the public sector (i.e., other national laboratories), and 3) comparisons with private-sector peer groups. Figure 5 illustrates this progression as currently planned. We intend to conduct internal benchmarks and develop service-level agreements as a first step. From this, we will compile a subset of performance measures that are

- important to our internal customers and significant in terms of business alignment

- comparable externally (and of value to our benchmarking peers).

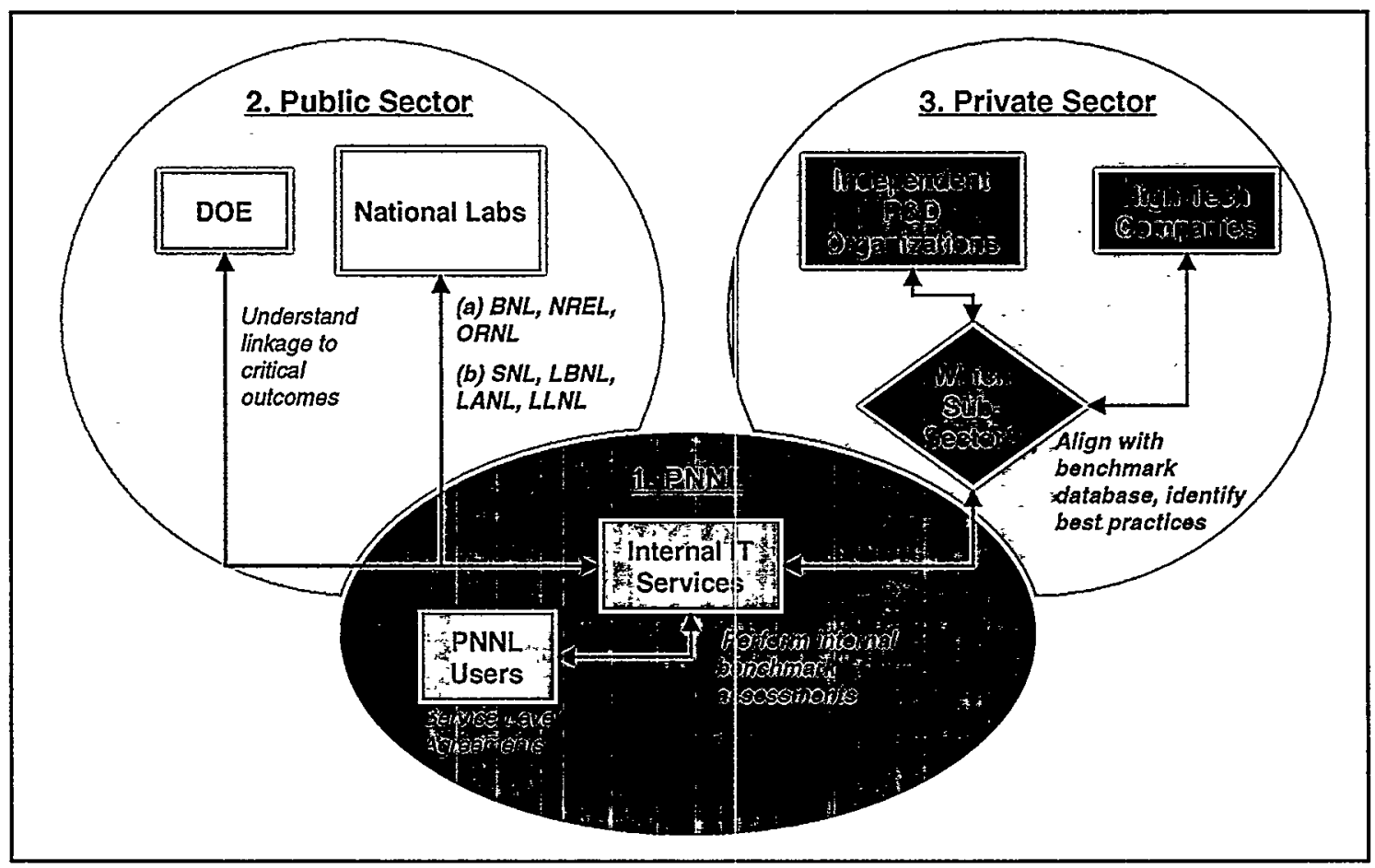

Figure 5. PNNL IT Benchmarking Plans

We also will pursue relationships with national laboratories. Initially, we will work with Brookhaven, National Renewable Energy, and Oak Ridge, because they previously expressed an interest in benchmarking with PNNL and they have similar business objectives. Performance data may be difficult to normalize, because IT services and architectures are quite different. In FY2000, we will expand our national laboratory IT benchmarking peer relationships to include others, such as Sandia, Lawrence Berkeley, Los Alamos, and Lawrence Livermore.

When we looked at peers in the private sector, we were unable to clearly define a useful sub-sector that compared well with our business objectives and IT services architecture. However, we did find some consultant firms with IT benchmarking experience that partner with firms in the private sector and normalize the information to make it comparable. We intend to purchase benchmarking services next year, rather than seeking out, establishing, and maintaining our own benchmarking peer relationships in the private sector.

What is the benefit of investing the time and effort required to perform effective IT benchmarking? The primary benefit is increased credibility with senior executives - i.e., assurance that their IT investments can be wisely made. Making no formal comparisons of IT services against peers decreases credibility and increases the leverage of potential external service providers who will always discover compelling performance statistics. In fact, executives are requiring or soon will require such comparisons because I'T investments are increasingly recognized as critical to competitive advantage. 
For each IT service area, knowing an organization's position relative to best practices is valuable. Better decisions can be made on investments, focusing scarce resources in areas that most enhance competitive advantage in chosen markets. For example, in the next five years significant investments in networking infrastructure will be required by most organizations. How can organizations best deliver installed network capacity (in the form of available network bandwidth) to meet business requirements, and how does that compare with peers? Connectivity to the Internet is becoming increasingly critical to many businesses. How much of the installed Internet capacity is actually used across a selected peer group? What does that imply about future investments? Figure 6 illustrates such a comparison, which can be used to understand differences among peers and identify best practices. Benchmarking collaborators can then adapt best practices for themselves, as appropriate for their individual circumstances.

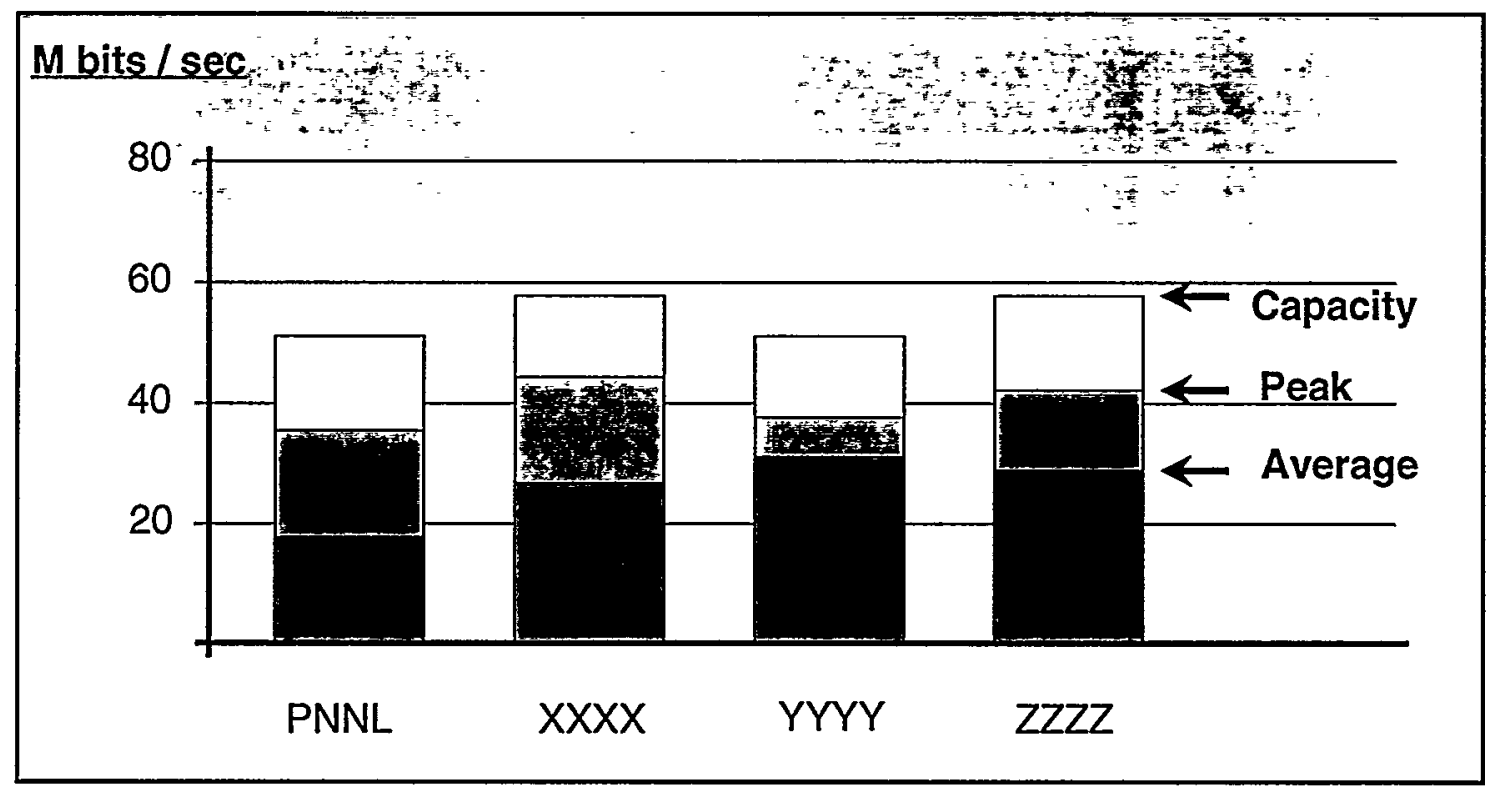

Figure 6. Peer Group Comparison of Internet Use (Capacity, Peak, Average)

\section{References}

1. American Productivity and Quality Center (benchmarking clearinghouse of which PNNL is a member). Available URL: http://www.apqc.org/

2. Baskin, Ralph. 1999. "Building a Successful IT Overview Measurement Program." In Proceedings of the IT Measurement for Business Performance and Alignment Conference, pp. 10-11. June 2-4, 1999.

3. Heine, Jack. 1999. "Calibrating the IT Environment." In Proceedings of the GartnerGroup IT Measurement for Business Performance and Alignment Conference, p. 8. June 2-4, 1999.

4. Kaplan, Robert S. and David P. Norton. 1996. The Balanced Scorecard: Translating Strategy into Action. Harvard Business School Press. 